\title{
USE OF PHOTOLYSIS (ARTIFICIAL RADIATION- UV) AS AN ADVANCED OXIDATION PROCESS (AOP) FOR POLISHING SWINE WASTEWATER TREATED IN ANAEROBIC REACTORS
}

\author{
Erlon Lopes Pereira ${ }^{1}$, Claudio Milton Montenegro Campos², Regina Batista Vilas Boas ${ }^{3}$, Cristine Serafini Neves ${ }^{4}$
}

\begin{abstract}
Among the numerous processes reported for sterilization of contaminated effluents, the advanced oxidative process (AOP) stands out for being effective in polishing degrading dissolved organic compounds. When comparing the various $\mathrm{AOP}(\mathrm{s})$, the UV photic process is advantageous since does not use catalysts and oxidizing reagents but only UV degradation, thus resulting in an effluent suitable for reuse and avoiding financial expenses related to chemical consumption. The present study sought after evaluating the efficiency of UV light, generated by special lamps in photo-reactors, degrading dissolved compounds and sterilizing microorganisms present in the effluent of anaerobic reactors treating hog farm effluents, aimed at improving the quality of the treated wastewater. In this work, two photoreactors were constructed using PVC pipe measuring $100 \mathrm{~mm}$ in diameter and $1060 \mathrm{~mm}$ in length. The pipe ends were sealed with PVC caps and the photo-reactor lamps designed to act on the liquid surface, without immerse in the liquid. Photo-reactors coated with aluminum foil increased the efficiency of UV radiation. The lamp used in each of the reactors was the germicidal fluorescent type, with wavelength of $240 \mathrm{~nm}$ and power of 30 Watts. In all trials, the photic process observed using only UV radiation was not efficient for mineralization of soluble organic compounds, however with this process it was possible to modify the biodegradability of wastewater from pig farming.
\end{abstract}

Keywords: water reuse, tertiary treatment, fertigation, photo-degradation, biodegradability

\section{RESUMO}

\section{USO DA FOTÓLISE (UV ARTIFICIAL) COMO PROCESSO OXIDATIVO AVANÇADO (POA) NO POLIMENTO DA ÁGUA RESIDUÁRIA DA SUINOCULTURA TRATADA EM REATORES ANAERÓBIOS}

Dentre os processos em ascensão para polimento de efluentes, os Processos Oxidativos Avançados (POA) destacamse por serem eficientes nessa missão, o que é decorrente da degradação de compostos orgânicos dissolvidos. Dentre os POA(s), o processo fótico UV é vantajoso por não utilizar catalisadores e oxidantes, ou seja, apenas a luz UV na degradação, produzindo, assim, um efluente adequado para reuso na própria suinocultura ou como fertilizante ou despejo em cursos hídricos. Visto o exposto, no presente estudo buscou-se avaliar a eficiência da radiação UV, gerada por meio de lâmpadas especiais, em reatores fóticos, na degradação de compostos orgânicos dissolvidos, presentes no efluente de suinocultura tratado em reatores anaeróbios, visando a melhoria da qualidade do efluente tratado. Para isso, utilizaram-se dois reatores fóticos construídos de tubos PVC brancos de $100 \mathrm{~mm}$ de diâmetro e $1060 \mathrm{~mm}$ de comprimento. Suas extremidades foram lacradas com tampões de PVC. Os reatores fóticos foram desenvolvidos para atuar sobre o espelho líquido, sem que a lâmpada entrasse em contato com o efluente líquido. Para aumentar a eficiência da radiação UV, o reator foi revestido com papel de alumínio. A lâmpada utilizada em cada um dos reatores foi do tipo fluorescente germicida, com comprimento de onda da faixa de $240 \mathrm{~nm}$, potência de 30 Watts. Em todos os ensaios observou-se o processo fótico utilizando apenas radiação UV não foi eficiente na mineralização dos compostos orgânicos solúveis, todavia, com o esse processo foi possível modificar a biodegradabilidade da água residuária de suinocultura.

Palavras-chave: água de reuso, tratamento terciário, fertirrigação, fotodegradação, biodegradabilidade.

\section{Recebido para publicação em 18/08/2014. Aprovado em 16/03/2015.}

1 - Engenheiro Agrícola. Doutorando no Programa de Pós-graduação em Eng. Agrícola. DEA/UFV. erlonlopes@gmail.com

2 - Engenheiro Civil. PhD em Environmental Engineering. Professor Associado IV do Departamento de Engenharia, UFLA

3 -Licenciada em Química. Doutoranda no Programa de Pós-graduação em Engenharia Agrícola. Dpto. de Engenharia, UFLA

4 - Licenciada em Química e Engenheira Química. Mestre em Engenharia Agrícola. Departamento de Engenharia, UFLA

228 REVENG 228-240p.

ENGENHARIA NA AGRICULTURA, VIÇOSA - MG, V.23 N.3, MAIO / JUNHO 2015 


\section{INTRODUCTION}

One of the most significant events in the field of wastewater management was the Federal Water Pollution Control Act Amendments of 1972 (Public Law 92-500), usually referred to as the Clean Water Act (CWA). Prior to this date, there were no specific objectives with regard to the control of water pollution. The CWA not only established important objectives and goals (to restore and maintain the chemical, physical and biological integrity of the waters), but also marked a radical change in the philosophy of water pollution control. The CWA was established to improve water quality by imposing specific limitations. The NPDES program (National Pollution Discharge Elimination System) was established based on a minimum technology that each point of discharge would have to meet. In Brazil, the National Environmental Council (CONAMA) through Resolution 357/2005 (CONAMA, 2005), classifies water bodies concerning its water quality standards and the discharge of liquid effluents must follow the same pattern. States may legislate on this matter, with the condition that the State Laws may be more restrictive than the Federal Legislation (PEREIRA et al., 2010a).

Nowadays, many Brazilian agro-industrial wastewaters have been treated, seeking to remove organic matter, especially particulate matter, using biological (aerobic and anaerobic) or physical treatment units, such as decanters, sand filters or even organic filters. Efficiency is generally estimated in relation to $\mathrm{BOD}_{5}{ }^{20^{\circ} \mathrm{C}}$ or total $\mathrm{COD}$, and few works evaluate filterable organic compounds (dissolved volatile solids) as a source of pollution. It is important to consider that the dissolved volatile solids from biological treatment systems are generated from the degradation of suspended solids, which were not yet biologically stabilized and can still consume oxygen when discharged into water bodies. These solids can also act as a habitat for pathogens colonies, modifying the color of treated effluent, and in many cases limiting the forms of reuse. Additionally, these dissolved compound contaminants can masquerade toxins and other micro-pollutants (SUBTIL et al., 2009; PEREIRA et al., 2011b).
In many situations where the effluent is traditionally treated and there is still opportunity for removal of dissolved solids, it becomes necessary to employ a tertiary treatment for final polishing. Currently, scientific advances have allowed for the polishing process using the advanced oxidative process (AOP), which effectively applies techniques for the treatment of dissolved recalcitrant compounds capable of eliminating compounds resistant to primary (physical and biochemical) and secondary (biological) treatments, and can be applied to both inorganic and organic, biodegradable and non-biodegradable compounds. With respect to dissolved organic compounds, the advantage is the elimination of pollutants, transforming them into inert products including $\mathrm{CO}_{2}, \mathrm{H}_{2} \mathrm{O}$ and mineral acids. (FERREIRA and DANIEL, 2004; ABREU et al., 2013).

Salgado et al. (2009), using advanced oxidation processes in dye solutions from industrial textile effluents, completely eliminated the color of synthetic products when employing the Fenton process for just three minutes, and within five minutes when submitted to oxidation with hydrogen peroxide and UV light $\left(\mathrm{UV} / \mathrm{H}_{2} \mathrm{O}_{2}\right)$. In the effluent, the best result of discoloration was obtained by the Fenton reaction in just three minutes, while the photochemical process removed the same percentage of color in five minutes. With respect to the degree of the effluent mineralization, a large reduction in organic matter content is observed via removal of COD using Fenton and $\mathrm{UV} / \mathrm{H}_{2} \mathrm{O}_{2}$, around $50 \%$ and $33 \%$, respectively, while when employing the photolytic mechanisms it was around $17 \%$. The use of oxidizers or catalysts can further restrict use of the liquid effluent in fertigation.

In the present study it was sought to evaluate the efficiency of UV light generated by special lamps in photo-reactors for the modification of biodegradability $\left(\mathrm{BOD}_{5}{ }^{20^{\circ} \mathrm{C}} / \mathrm{COD}\right)$ and degradation of dissolved compounds normally present in the effluent of anaerobic reactors.

\section{MATERIAL AND METHODS}

The treated liquid effluent used was obtained from a pilot scale treatment system, treating hog 
farm effluent. This treatment system was installed at the Department of Animal Science at the Federal University of Lavras (UFLA). Preliminary treatment was constructed with a Sand Retention Box (SRB), a Stainless Steel Sieve (SSS), Static Equalization and Acidification Tank (SEAT), Anaerobic Baffled Reactor (ABR), Anaerobic Sludge Blanket Reactor (UASB) and a Settling Tank (ST). Additional publications provide more information on the system structure, including those of Pereira et al. (2009), Pereira et al. (2010a); Pereira et al. (2010b) and Pereira et al. (2011a).

The two photo-reactors were constructed using PVC tubes measuring $100 \mathrm{~mm}$ in diameter and 1060 $\mathrm{mm}$ in length, whose ends were sealed with PVC caps. For insertion of the UV lamp a cut was made to the upper side of the tube of rectangular shape, with a length of $920 \mathrm{~mm}$ and $50 \mathrm{~mm}$ in width. The UV lamp was fixed using another PVC pipe cut into a half-circle, which had an opening of 940 $\mathrm{mm}$ in length and $100 \mathrm{~mm}$ in width, within which 3 steel brackets were installed for fitting and fixing of the UV lamp. The detailed construction steps are shown in Figure 1. The photo-reactor operated without UV lamp submersion, therefore, the lamp was held above the reflecting surface of the liquid. To increase the degree of reflectance, the tube was coated with aluminum foil, as shown in Figure 2. The germicidal fluorescent light bulb employed presented the following characteristics: power of 30 Watts, wavelength of $240 \mathrm{~nm}$, manufactured by Techlux. Each photo-reactor had a net storage volume of $1.5 \mathrm{~L}$, where the wastewater level was maintained at $4 \mathrm{~cm}$ along its length.

During the study six tests were conducted, each of which was subdivided into two treatments, totaling 12 treatments. The differences between each test were the values of influent concentrations with regards to chemical oxygen demand $\left(\mathrm{COD}_{\mathrm{S}}\right)$ and biochemical oxygen demand $\left(\mathrm{BOD}_{5}^{20^{\circ} \mathrm{C}} \mathrm{S}\right)$ in soluble forms, and total dissolved solids (TDS). Influent concentration variations were due to efficiency of the biological treatment system that preceded the photo-reactors. In an attempt to control the concentration variations a $3000 \mathrm{~L}$ container was installed upstream of the photo-reactors to collect
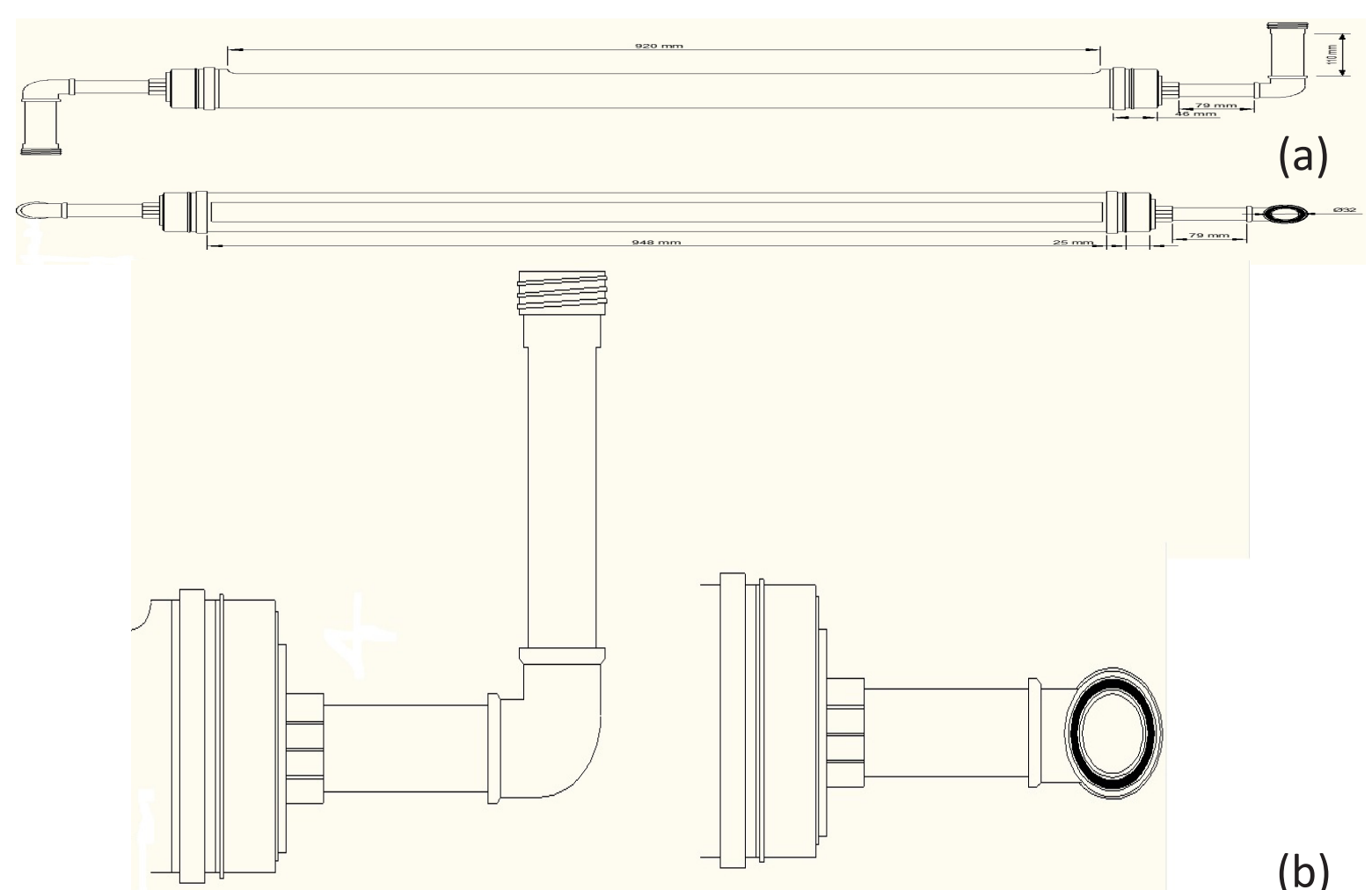

(b)

Figure 1. Schematic diagram of the photo-reactors: (a) Side view of the photo-reactor. (b) Details of the PVC Cap (socket $-\Phi 100 \mathrm{~mm}$ ) at the extremes of the photo-reactor 


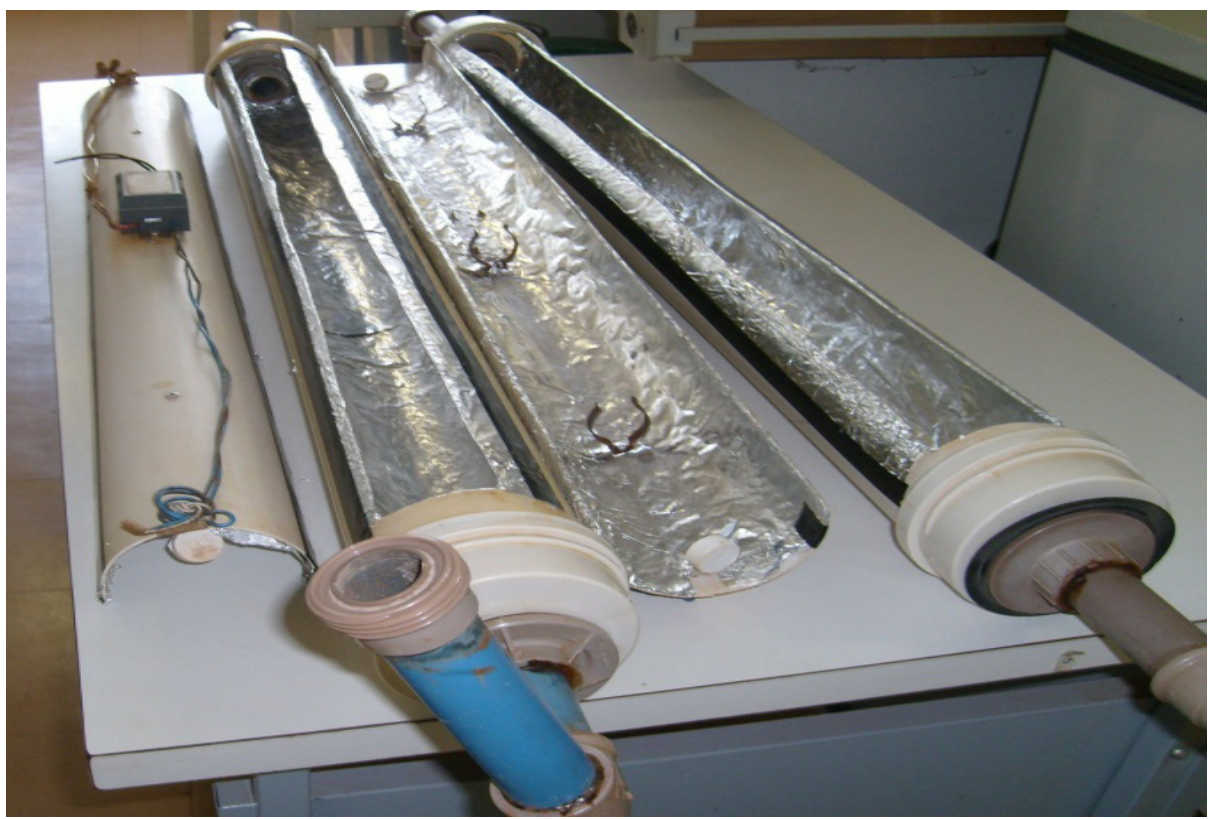

Figure 2. Photo-reactors coated with aluminum foil.

the treated swine wastewater throughout one day, and exposed to UV light in the photo-reactors after storage and homogenization. Control of the flow rate $(\mathrm{Q})$ was performed by means of a flow valve installed at the inlet of each photo-reactor, where for each individual treatment the hydraulic retention time value (HRT) was calculated. Because the UV lamp remained in operation throughout the test, the HRT value is equal to the time during which the liquid was under the influence of UV radiation. The HRT value applied in each treatment was calculated using Equation 1.

$$
H R T=\frac{V}{Q}
$$

where,

HRT: Hydraulic Retention Time (h)

Q: Flow $\left(\mathrm{L} \mathrm{h}^{-1}\right)$;

V: Net volume of photo-reactor

Due to variation of the influent concentration in each test, 12 different organic loadings were found in terms of total dissolved solids (TDSL), chemical oxygen demand (CODL) and biochemical oxygen demand (BODL).These loadings were applied to the 12 treatments evaluated during the 6 tests. The values of applied loadings were calculated according to equations 2, 3, 4 and 5 .
$T D S L=$ Conc $_{\cdot T D S} x Q$

$C O D L=$ Conc $_{\text {COD }} x Q$

$B O D L=$ Conc $_{B O D} x Q$

$O L R=\frac{\text { Conc }_{\cdot C O D} x Q}{V}$

where,

TDSL: Total Dissolved Solids Loading rate $\left(\mathrm{gTDS} \mathrm{d}^{-1}\right)$; CODL: Soluble Chemical Oxygen Demand Loading rate $\left(\mathrm{gCOD} \mathrm{d}^{-1}\right)$;

BODL: Soluble Biochemical Oxygen Demand Loading rate $\left(\mathrm{gBOD} \mathrm{d}^{-1}\right)$;

VOLR: Volumetric Organic Loading rate in terms of soluble COD;

Conc. TDs: Total Dissolved Solids affluent concentration $\left(\mathrm{g} \mathrm{L}^{-1}\right)$;

Conc. CoDs: Soluble Chemical Oxygen Demand affluent concentration $\left(\mathrm{g} \mathrm{L}^{-1}\right)$;

Conc. вор: Soluble Biochemical Oxygen Demand affluent concentration $\left(\mathrm{g} \mathrm{L}^{-1}\right)$;

Q: Flow rate $\left(\mathrm{L} \mathrm{h}^{-1}\right)$.

$\mathrm{V}$ : Net volume of the photo-reactor 
Table 1. Physical-chemical analyzed parameters.

\begin{tabular}{cc}
\hline Physical-chemical Parameters & Bibliography \\
$\mathrm{pH}$ & APHA, AWWA, WPCF (2005) \\
Soluble Chemical Oxygen Demand $\left(\mathrm{COD}_{\mathrm{S}}\right)$ & APHA, AWWA, WPCF (2005) \\
Soluble Biochemical Oxygen Demand $\left(\mathrm{BOD}_{5}{ }^{2{ }^{\circ} \mathrm{C}} \mathrm{s}\right)$ & APHA, AWWA, WPCF (2005) \\
Total Dissolved Solids (TDS), Fixed (FDS) and Volatile (VDS) & APHA, AWWA, WPCF (2005) \\
Turbidity & Turbity-meter - Hach \\
\hline ES: Conductivity-meter - Hach
\end{tabular}

PS.: The analyses of $\mathrm{COD}_{\mathrm{S}}$; $\mathrm{BOD}_{5}{ }^{20^{\circ} \mathrm{C}}{ }_{\mathrm{s}}$; TDS, FDS and VDS were performed by filtering the affluent and effluent samples through a fiberglass membrane with porosity of $0.45 \mu \mathrm{m}$.

Physicochemical evaluation was carried out by collecting samples in sanitized bottles, with three repetitions. Composite samples of $500 \mathrm{~mL}$ were gathered to increase the quality of the analysis. The collected bottles with samples were placed in a styrofoam box and taken for analysis at the Water Analysis Laboratory of the Engineering Department (LAADEG/UFLA). The physical and chemical parameters analyzed are shown in Table 1.

Values of the $\mathrm{BOD}_{5}^{20^{\circ} \mathrm{C}} \mathrm{S} / \mathrm{COD}_{\mathrm{S}}$ ratio were used as indicator of biodegradability in the wastewater influent and effluent of each treatment. For analysis of the results descriptive statistic parameters were used, including averages (A), variation coefficients (VC) and standard deviations (SD), determined from three repetitions. To determine if there was statistical difference between the two treatments studied within each individual test (Table 2), or between the influent and effluent of each treatment (tables 3 to 8), the Student's test was applied (t-test). Lowercase letters next to the value displayed were used to indicate equality or difference between the values analyzed. Different letters indicate that the averages differ by more than $5 \%$ by the t-test, so $5 \%$ significant probability $(\mathrm{p}<0.05)$, however the same letters indicate that there is no statistically significant difference among averages at the 5\% probability level $(p>0.05)$. The statistical analyses were carried out using the statistical software SISVAR (version 4.0) (FERREIRA, 2011).

\section{RESULTS AND DISCUSSIONS}

The operational parameters of flow rate $(\mathrm{Q})$, hydraulic retention time (HRT), organic loading rates in terms of total dissolved solids (TDSL), chemical oxygen demand (CODL) and biochemical oxygen demand (BODL) applied to the photoreactors for the 12 treatments and evaluated in 6 tests are shown in Table 2.

As can be observed in Table 2, when analyzing the results obtained for the parameters Q, HRT, TDSL, CODL and BODL, significant statistical differences were observed at $5 \%$ probability $(\mathrm{p}<0.05)$ by the $\mathrm{t}$-test. Therefore, it is possible to conclude that the photo-reactors operated with different loadings and flow values, along with increased hydraulic detention time; consequently the UV radiation exposure time varied when comparing the two treatments within the same test over the six tests.

Lim et al. (2013) studied the effect of electron beam irradiation on the treatment of wastewater from pig farming. The authors maintained a constant volumetric organic loading rate (OLR) in terms of soluble COD, valued at $1.9 \mathrm{~g} \mathrm{~L}^{-1} \mathrm{~d}^{-1}$ with HRT of 5 days, varying only the electron beam radiation from 0 to $100 \mathrm{kGy}$. The authors concluded that for the OLR conditions and HRT studied, the radiation doses that led to greatest efficiency in COD removal were between 20 and $75 \mathrm{kGy}$. The useful volume of the photo-reactor used in this experiment was $1.5 \mathrm{~L}$, as described in the Materials and Methods, based on CODL data as shown in Table 2; and when using Equation 5 it was concluded that the photo-reactors of this research have undergone OLR variations in terms of soluble COD values from 35.5 to $4177.3 \mathrm{~g} \mathrm{~L}^{-1} \mathrm{~d}^{-1}$. Therefore, the values of the parameters studied in this study are above the loading values referenced in literature, where

\section{REVENG}


Table 2. Operational parameters of the photo-reactors and statistical comparison of means $(t$ test) for the treatments performed in each test.

\begin{tabular}{|c|c|c|c|c|c|c|c|}
\hline \multirow{2}{*}{ Experiment } & \multirow{2}{*}{ Treatment } & \multirow{2}{*}{$\begin{array}{c}\mathrm{Q} \\
\mathrm{L} \mathrm{h}^{-1}\end{array}$} & \multirow{2}{*}{$\begin{array}{l}\text { HRT } \\
\min \end{array}$} & \multirow{2}{*}{$\begin{array}{c}\text { HRT } \\
\mathrm{h}\end{array}$} & TDSL & CODL & BODL \\
\hline & & & & & \multicolumn{3}{|c|}{$\mathrm{g} \mathrm{d}^{-1}$} \\
\hline \multirow{2}{*}{ E1 } & $\mathrm{T} 1$ & $182.62 \mathrm{a}$ & $0.4922 \mathrm{a}$ & $0.0082 \mathrm{a}$ & $9267.4 \mathrm{a} \pm 560.0$ & $6265.9 \mathrm{a} \pm 610.0$ & $2542.1 \mathrm{a} \pm 43.8$ \\
\hline & $\mathrm{T} 2$ & $143.96 \mathrm{~b}$ & $0.6252 b$ & $0.0104 \mathrm{~b}$ & $7305.5 b \pm 441.5$ & $4939.5 b \pm 480.8$ & $2003.9 b \pm 34.6$ \\
\hline \multirow{2}{*}{ E2 } & $\mathrm{T} 3$ & $61.86 \mathrm{a}$ & $1.4550 \mathrm{a}$ & $0.0243 \mathrm{a}$ & $3080.6 \mathrm{a} \pm 230.1$ & $3362.2 \mathrm{a} \pm 432.0$ & $1915.2 \mathrm{a} \pm 207.9$ \\
\hline & $\mathrm{T} 4$ & $32.07 \mathrm{~b}$ & $2.8062 b$ & $0.0468 \mathrm{~b}$ & $1597.1 b \pm 119.3$ & $1743.0 \mathrm{~b} \pm 224.0$ & $992.9 b \pm 107.8$ \\
\hline \multirow{2}{*}{ E3 } & T5 & $33.78 \mathrm{a}$ & $2.6647 \mathrm{a}$ & $0.0444 a$ & $1471.0 \mathrm{a} \pm 0.9$ & $2071.9 \mathrm{a} \pm 841.1$ & $1009.3 \mathrm{a} \pm 12.2$ \\
\hline & $\mathrm{T} 6$ & $6.14 b$ & $14.6498 b$ & $0.2442 b$ & $267.4 b \pm 0.2$ & $376.6 b \pm 152.9$ & $183.5 \mathrm{~b} \pm 2.2$ \\
\hline \multirow{2}{*}{ E4 } & $\mathrm{T} 7$ & 6.75 & $13.3370 \mathrm{a}$ & $0.2223 \mathrm{a}$ & $312.4 \mathrm{a} \pm 1.4$ & $422.2 \mathrm{a} \pm 57.4$ & $128.8 \mathrm{a} \pm 13.8$ \\
\hline & $\mathrm{T} 8$ & 6.14 & $14.6667 \mathrm{~b}$ & $0.2444 \mathrm{~b}$ & $284.2 b \pm 1.2$ & $384.1 \mathrm{~b} \pm 52.2$ & $117.2 b \pm 12.5$ \\
\hline \multirow{2}{*}{ E5 } & T9 & 5.24 & $17.1875 \mathrm{a}$ & $0.2863 \mathrm{a}$ & $259.2 \mathrm{a} \pm 6.3$ & $281.6 \mathrm{a} \pm 38.2$ & $167.3 \mathrm{a} \pm 3.8$ \\
\hline & $\mathrm{T} 10$ & 0.99 & $90.5560 \mathrm{~b}$ & $1.5151 \mathrm{~b}$ & $49.0 \mathrm{~b} \pm 1.2$ & $53.2 \mathrm{~b} \pm 7.2$ & $31.6 b \pm 0.7$ \\
\hline \multirow{2}{*}{ E6 } & $\mathrm{T} 11$ & 25.49 & $3.5310 \mathrm{a}$ & $0.0588 \mathrm{a}$ & $1249.5 \mathrm{a} \pm 246.2$ & $1656.3 \mathrm{a} \pm 46.4$ & $244.7 \mathrm{a} \pm 73.4$ \\
\hline & T12 & 7.32 & $12.2980 \mathrm{~b}$ & $0.2049 b$ & $358.8 b \pm 70.7$ & $475.6 b \pm 13.3$ & $70.3 b \pm 21.1$ \\
\hline
\end{tabular}

Q: flow applied to photo-reactor. HRT: hydraulic retention time; TDSL: organic loading rate in terms of total dissolved solids. CODLs: organic loading rate in terms of soluble chemical oxygen demand. BODLs: organic loading rate in terms of soluble biochemical oxygen demand.

Table 3. Results of the physicochemical analysis of test 1 and statistical comparison between the averages of the influent and effluent of treatments 1 (T1) and 2 (T2).

\begin{tabular}{lcccccc}
\hline \multirow{2}{*}{ Parameter } & \multicolumn{2}{c}{ Influents of T1 and T2 } & \multicolumn{2}{c}{ Effluent T1 } & \multicolumn{2}{c}{ Effluent T2 } \\
\cline { 2 - 7 } & $\mathrm{A} \pm \mathrm{SD}$ & $\mathrm{V} . \mathrm{C} .(\%)$ & $\mathrm{A} \pm \mathrm{SD}$ & V. C. $(\%)$ & $\mathrm{A} \pm \mathrm{SD}$ & V. C. (\%) \\
\hline Turbidity & $1037.0 \mathrm{a} \pm 5.0$ & 0.5 & $1054.7 \mathrm{a} \pm 5.7$ & 0.5 & $1052.0 \mathrm{a} \pm 9.6$ & 0.9 \\
EC & $2.3 \mathrm{a} \pm 0.1$ & 4.8 & $2.5 \mathrm{a} \pm 0.03$ & 1.4 & $4.1 \mathrm{a} \pm 1.3$ & 31.5 \\
TDS & $2114.4 \mathrm{a} \pm 127.8$ & 6.0 & $2010.0 \mathrm{a} \pm 58.4$ & 2.8 & $2080.0 \mathrm{a} \pm 45.6$ & 0.7 \\
VDS & $887.8 \mathrm{a} \pm 14.4$ & 1.6 & $848.1 \mathrm{a} \pm 98.9$ & 11.7 & $954.8 \mathrm{a} \pm 43.0$ & 4.5 \\
$\mathrm{CODS}$ & $1429.6 \mathrm{a} \pm 139.2$ & 9.7 & $1214.6 \mathrm{a} \pm 45.6$ & 3.8 & $1752.3 \mathrm{a} \pm 615.2$ & 35.1 \\
$\mathrm{BOD}_{5}{ }^{20^{\circ} \mathrm{C}} \mathrm{S}$ & $580.0 \mathrm{a} \pm 10.0$ & 1.7 & $626.7 \mathrm{a} \pm 96.1$ & 15.0 & $606.7 \mathrm{~b} \pm 11.6$ & 1.9 \\
$\mathrm{BOD}_{5}{ }^{20^{\circ} \mathrm{C}}{ }_{\mathrm{S}} / \mathrm{COD}_{\mathrm{S}}$ & $0.4 \mathrm{a} \pm 0.03$ & 8.0 & $0.5 \mathrm{a} \pm 0.07$ & 13.9 & $0.4 \mathrm{a} \pm 0.2$ & 41.0 \\
\hline
\end{tabular}

Where: Turbidity (NTU), EC: Electrical Conductivity $\left(\mathrm{mS} \mathrm{cm}^{-1}\right)$, TDS: Total Dissolved Solids ( $\left.\mathrm{mg} \mathrm{L}^{-1}\right)$, VDS: Volatile Dissolved Solids $\left(\mathrm{mg} \mathrm{L}^{-1}\right), \mathrm{BOD}_{5}^{20^{\circ} \mathrm{C}} \mathrm{s}_{\mathrm{s}}$ : Soluble Biochemical Oxygen Demand $\left(\mathrm{gO}_{2} \mathrm{~m}^{-3}\right), \mathrm{COD}_{\mathrm{s}}$ : Soluble Chemical Oxygen Demand $\left(\mathrm{gO}_{2} \mathrm{~m}^{-3}\right), \mathrm{BOD}_{5}^{20^{\circ} \mathrm{C}} \mathrm{s}_{\mathrm{S}} / \mathrm{COD}_{\mathrm{S}}$ : dimensionless. 
the photo-reactors operated with high organic loadings and used a simpler radiation source to that studied by Lim et al. (2013). By applying the operational parameters described in Table 2 to the photo-reactors, the results for each test studiedwere obtained, which are presented in tables $3,4,5,6$, 7 and 8 . Table 3 presents the turbidity values, EC and concentrations of VDS, CODs, $\mathrm{BOD}_{5}^{20^{\circ} \mathrm{C}} \mathrm{S}$ and the $\mathrm{BOD}_{5}{ }^{20^{\circ} \mathrm{C}}$ / CODs ratio that characterize the influent and effluent treatments 1 and 2 .

When analyzing turbidity, EC, TDS, VDS, CODS and $\mathrm{BOD}_{5}{ }^{20{ }^{\circ} \mathrm{S}} \mathrm{S} / \mathrm{CODs}$, statistically significant difference was observed among parameters at $5 \%$ probability $(\mathrm{p}>0.05)$ between the influent and effluent of T1 and T2. However, for the concentration of $\mathrm{BOD}_{5}{ }^{2{ }^{\circ} \mathrm{C}}$ statistically significant differences were observed at $5 \%$ probability $(\mathrm{p}<0.05)$ between influent and effluent averages for T2 (HRT 0.62 minutes), showing that operational and physicochemical conditions of wastewater submitted to the photo-reactor resulted in an increase in the concentration of $\mathrm{BOD}_{5}{ }^{20^{\circ} \mathrm{C}}$ of the effluent in relation to its influent. Even with the increase in $\mathrm{BOD}_{5}{ }^{2{ }^{\circ} \mathrm{C}}$ concentration in the effluent sample of T2, no change in biodegradability was observed for this sample (Table 3). Table 4 shows the Turbidity and EC values, concentrations of

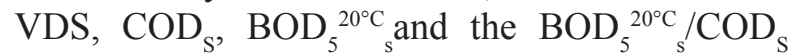
ratio that characterize the influent and effluent of treatments 3 and 4 .

According to Table 4 for the TDS concentration and turbidity parameters no significant statistical differences were observed at $5 \%$ probability $(p>0.05)$ between the average influent and effluent of T3 and T4. For the remaining parameters a statistically significant difference $(p<0.05)$ was observed between the influents and effluents of T3 and T4, highlighting the increase in EC in the effluent values of $\mathrm{T} 3$ and $\mathrm{T} 4$, increase in the concentrations of $\mathrm{COD}_{\mathrm{S}}$ and VDS in the effluent of T3 only, and decrease in concentration of $\mathrm{BOD}_{5}{ }^{20^{\circ} \mathrm{C}}{ }_{5}$ only in the effluent sample of T4. Consequently, the increased $\mathrm{COD}_{\mathrm{S}}$ concentration in the effluent of samples $\mathrm{T} 3$ and T4 caused a decrease in their biodegradability (Table 4). Therefore, it was concluded that the operational conditions of the Test 2, treatments T3 (TDH of 1.5 minutes) and T4 (TDH of 2.8 minutes), resulted in a decrease in biodegradability of the treated effluent in relation the influent. Table 5 shows the values of $\mathrm{pH}$, turbidity, EC, concentrations of VDS, CODS, BODs ${ }_{5}^{20^{\circ} \mathrm{C} \text { and }}$ $\mathrm{BOD}_{5}{ }^{20}{ }^{\circ} \mathrm{C} / \mathrm{COD}_{\mathrm{S}}$ ratio that characterize the influent and effluent of treatments 5 and 6 .

Table 5 shows that statistically significant differences occurred $(p<0.05)$ between the influent and effluentof T 5 and T6 for all evaluated parameters, except for the parameter CODs concentration. Highlighted were the decrease in $\mathrm{BOD}_{5}{ }^{20^{\circ} \mathrm{C}} \mathrm{s}$ concentration, turbidity and biodegradability of the effluent in T5 (TDH of 2.7 minutes) and T6 (TDH of 14.6 minutes) for effluent samples of treatments 5 and 6 in relation to the influent. Table 6 presents

Table 4. Results of the physicochemical analysis of test 2 and statistical comparison between averages of the influent and effluent of treatments 3 (T3) and 4 (T4).

\begin{tabular}{lcccccc}
\hline \multirow{2}{*}{ Parameter } & \multicolumn{2}{c}{ Influents T3 and T4 } & \multicolumn{2}{c}{ Effluent T3 } & \multicolumn{2}{c}{ Effluent T4 } \\
\cline { 2 - 7 } & $\mathrm{A} \pm \mathrm{SD}$ & V. C. $(\%)$ & $\mathrm{A} \pm \mathrm{SD}$ & V. C. $(\%)$ & $\mathrm{A} \pm \mathrm{SD}$ & V. C. (\%) \\
\hline Turbidity & $1100.0 \mathrm{a} \pm 0.0$ & 0.0 & $1107.3 \mathrm{a} \pm 25.0$ & 2.3 & $1062.0 \mathrm{a} \pm 20.8$ & 1.9 \\
EC & $2.5 \mathrm{a} \pm 0.0$ & 0.2 & $8.9 \mathrm{~b} \pm 0.1$ & 1.0 & $10.2 \mathrm{~b} \pm 0.2$ & 2.2 \\
TDS & $2075.0 \mathrm{a} \pm 155.0$ & 7.5 & $2227.8 \mathrm{a} \pm 34.7$ & 1.6 & $1873.3 \mathrm{a} \pm 151.7$ & 8.1 \\
VDS & $1220.0 \mathrm{a} \pm 86.7$ & 7.1 & $1432.2 \mathrm{~b} \pm 42.5$ & 3.0 & $1194.4 \mathrm{a} \pm 98.3$ & 8.2 \\
$\mathrm{COD}_{\mathrm{S}}$ & $2264.6 \mathrm{a} \pm 291.0$ & 12.8 & $3548.5 \mathrm{~b} \pm 6.3$ & 0.2 & $2884.6 \mathrm{a} \pm 701.3$ & 24.3 \\
$\mathrm{BOD}_{\mathrm{S} 5}{ }^{20^{\circ} \mathrm{C}}$ & $1290.0 \mathrm{a} \pm 140.0$ & 10.9 & $1286.7 \mathrm{a} \pm 167.7$ & 13.0 & $785.0 \mathrm{~b} \pm 25.0$ & 3.2 \\
$\mathrm{BOD}_{\mathrm{S} 5}{ }^{20^{\circ} \mathrm{C}} / \mathrm{COD}_{\mathrm{S}}$ & $0.6 \mathrm{a} \pm 0.1$ & 2.0 & $0.4 \mathrm{~b} \pm 0.04$ & 13.2 & $0.3 \mathrm{~b} \pm 0.08$ & 29.0 \\
\hline $\mathrm{W}^{2}$ & &
\end{tabular}

Where: Turbidity (NTU), EC: Electrical Conductivity $\left(\mathrm{mS} \mathrm{cm}^{-1}\right)$, TDS: Total Dissolved Solids ( $\left.\mathrm{mg} \mathrm{L}^{-1}\right)$, VDS: Volatile Dissolved Solids ( $\left.\mathrm{mg} \mathrm{L}^{-1}\right), \mathrm{BOD}_{\mathrm{S} 5}{ }^{20^{\circ} \mathrm{C}}$ : Soluble Biochemical Oxygen Demand $\left(\mathrm{mgO}_{2} \mathrm{~L}^{-1}\right), \mathrm{COD}_{\mathrm{S}}$ : Soluble Chemical Oxygen Demand $\left(\mathrm{mgO}_{2} \mathrm{~L}^{-1}\right), \mathrm{BOD}_{\mathrm{S}_{5}}{ }^{20^{\circ}} \mathrm{C} / \mathrm{COD}_{\mathrm{S}}$ : dimensionless. 
the values of $\mathrm{pH}$, turbidity, $\mathrm{EC}$, concentrations of VDS, CODS, $\mathrm{BOD}_{5}{ }^{20^{\circ} \mathrm{C}} \mathrm{s}$ and $\mathrm{BOD}_{5}{ }^{20^{\circ} \mathrm{C}} / \mathrm{COD}_{\mathrm{S}}$ ratio that characterize the influent and effluent of treatments 7 and 8 .

As shown in Table 6 significant statistic difference was observed $(\mathrm{p}<0.05)$ between the influent and effluent of T7 (TDH of 13.3 minutes) and T8 (TDH of 14.7 minutes), for the parameters $\mathrm{pH}$ and turbidity, TDS concentrations and VDS. However, with regards to the parameters of CODs and $\mathrm{BOD}_{5}{ }^{20} \mathrm{C}$ s concentration and biodegradation, a statistically significant difference $(\mathrm{p}<0.05)$ was observed only between average influent and effluent of $\mathrm{T} 8$, obtained in relation to the reduced influent concentration of $\mathrm{COD}_{\mathrm{S}}$, increased concentration of $\mathrm{BOD}_{5}{ }^{2{ }^{\circ} \mathrm{C}} \mathrm{S}$ and biodegradability. Table 7 presents values of turbidity, $\mathrm{pH}, \mathrm{EC}$, concentrations of VDS, CODs, $\mathrm{BOD}_{5}^{20^{\circ} \mathrm{C}}$ and the $\mathrm{BOD}_{5}^{20^{\circ} \mathrm{C}} / \mathrm{COD}_{\mathrm{S}}$ ratio that characterize the influent and effluent of treatments 9 and 10 .

Table 5. Results of the physicochemical analysis of test 3 and statistical comparison between the averages of the influent and effluent for treatments 5 (T5) and 6 (T6).

\begin{tabular}{lcccccc}
\hline \multirow{2}{*}{ Parameter } & \multicolumn{2}{c}{ Influents T5 and T6 } & \multicolumn{2}{c}{ Effluent T5 } & \multicolumn{2}{c}{ Effluent T6 } \\
\cline { 2 - 7 } & $\mathrm{A} \pm \mathrm{SD}$ & $\mathrm{V} . \mathrm{C} .(\%)$ & $\mathrm{A} \pm \mathrm{SD}$ & V. C. $(\%)$ & $\mathrm{A} \pm \mathrm{SD}$ & V. C. (\%) \\
\hline Turbidity & $1017.5 \mathrm{a} \pm 17.5$ & 1.7 & $893.0 \mathrm{~b} \pm 8.0$ & 0.9 & $870.0 \mathrm{~b} \pm 11.0$ & 1.3 \\
$\mathrm{pH}$ & $7.5 \mathrm{a} \pm 0.03$ & 0.3 & $7.5 \mathrm{a} \pm 0.05$ & 0.6 & $7.65 \mathrm{~b} \pm 0.01$ & 0.1 \\
$\mathrm{EC}$ & $4.6 \mathrm{a} \pm 0.05$ & 0.1 & $4.5 \mathrm{~b} \pm 0.0$ & 0.0 & $4.4 \mathrm{~b} \pm 0.0$ & 0.4 \\
$\mathrm{TDS}$ & $1814.4 \mathrm{a} \pm 1.1$ & 0.1 & $1726.7 \mathrm{~b} \pm 28.9$ & 1.7 & $1931.7 \mathrm{a} \pm 111.7$ & 5.7 \\
$\mathrm{VDS}$ & $720.0 \mathrm{a} \pm 15.6$ & 2.2 & $728.9 \mathrm{a} \pm 28.9$ & 4.0 & $586.7 \mathrm{~b} \pm 51.1$ & 8.7 \\
$\mathrm{COD}_{\mathrm{S}}$ & $2555.6 \mathrm{a} \pm 1037.4$ & 40.6 & $2909.9 \mathrm{a} \pm 50.6$ & 1.7 & $2909.9 \mathrm{a} \pm 999.5$ & 34.3 \\
$\mathrm{BOD}_{5}{ }^{20^{\circ} \mathrm{C}}$ & $1245.0 \mathrm{a} \pm 15.0$ & 1.2 & $955.0 \mathrm{~b} \pm 65.0$ & 6.8 & $757.0 \mathrm{~b} \pm 98.1$ & 13.0 \\
$\mathrm{BOD}_{5}{ }^{20^{\circ \mathrm{C}}} / \mathrm{COD}_{\mathrm{S}}$ & $0.6 \mathrm{a} \pm 0.2$ & 45.3 & $0.3 \mathrm{~b} \pm 0.02$ & 5.1 & $0.3 \mathrm{~b} \pm 0.08$ & 28.3 \\
\hline
\end{tabular}

Where: Turbidity (NTU), EC: Electrical Conductivity $\left(\mathrm{mS} \mathrm{cm}^{-1}\right)$, TDS: Total Dissolved Solids ( $\left.\mathrm{mg} \mathrm{L}^{-1}\right)$, VDS: Volatile Dissolved Solids $\left(\mathrm{mg} \mathrm{L}^{-1}\right), \mathrm{BOD}_{5}^{20^{\circ} \mathrm{C}}$ : Soluble Biochemical Oxygen Demand $\left(\mathrm{mgO}_{2} \mathrm{~L}^{-1}\right), \mathrm{COD}_{\mathrm{S}}$ : Soluble Chemical Oxygen Demand $\left(\mathrm{mgO}_{2} \mathrm{~L}^{-1}\right), \mathrm{BOD}_{5}^{20^{\circ} \mathrm{C}} \mathrm{S}_{\mathrm{S}} / \mathrm{COD}_{\mathrm{S}}$ : dimensionless.

Table 6. Results of the physicochemical analysis of 4 test and statistical comparison between the averages of the influent and effluent treatments 7 (T7) and 2 (T8).

\begin{tabular}{lcccccc}
\hline \multirow{2}{*}{ Parameter } & \multicolumn{2}{c}{ Influents T7 and T8 } & \multicolumn{2}{c}{ Effluent T7 } & \multicolumn{2}{c}{ Effluent T8 } \\
\cline { 2 - 7 } & $\mathrm{A} \pm \mathrm{SD}$ & $\mathrm{V} . \mathrm{C} .(\%)$ & $\mathrm{A} \pm \mathrm{SD}$ & V. C. $(\%)$ & $\mathrm{A} \pm \mathrm{SD}$ & V. C. (\%) \\
\hline Turbidity & $1030.0 \mathrm{a} \pm 3.0$ & 0.3 & $1007.0 \mathrm{~b} \pm 2.0$ & 0.2 & $991.0 \mathrm{~b} \pm 14.0$ & 1.4 \\
$\mathrm{pH}$ & $7.5 \mathrm{a} \pm 0.0$ & 0.1 & $7.7 \mathrm{~b} \pm 0.02$ & 0.3 & $7.7 \mathrm{~b} \pm 0.1$ & 0.8 \\
$\mathrm{EC}$ & $2.2 \mathrm{a} \pm 0.0$ & 0.7 & $2.2 \mathrm{a} \pm 0.01$ & 0.5 & $2.2 \mathrm{a} \pm 0.1$ & 2.6 \\
$\mathrm{TDS}$ & $1928.3 \mathrm{a} \pm 8.3$ & 0.4 & $2050.0 \mathrm{~b} \pm 3.3$ & 0.2 & $2101.1 \mathrm{~b} \pm 33.6$ & 1.6 \\
VDS & $1025.0 \mathrm{a} \pm 5.0$ & 0.5 & $1155.0 \mathrm{~b} \pm 31.7$ & 2.7 & $1201.7 \mathrm{~b} \pm 4.4$ & 0.4 \\
$\mathrm{COD}_{\mathrm{S}}$ & $2606.2 \mathrm{a} \pm 354.2$ & 13.6 & $1923.1 \mathrm{a} \pm 177.1$ & 9.2 & $1686.9 \mathrm{~b} \pm 31.8$ & 1.9 \\
$\mathrm{BOD}_{5}{ }_{\mathrm{O}}{ }_{\mathrm{O}} \mathrm{C}$ & $795.0 \mathrm{a} \pm 85.0$ & 10.7 & $710.0 \mathrm{a} \pm 180.0$ & 25.4 & $855.0 \mathrm{~b} \pm 75.0$ & 8.8 \\
$\mathrm{BOD}_{5}{ }^{20 \mathrm{C}}{ }_{\mathrm{S}} / \mathrm{COD}_{\mathrm{S}}$ & $0.3 \mathrm{a} \pm 0.01$ & 3.0 & $0.4 \mathrm{a} \pm 0.1$ & 16.5 & $0.5 \mathrm{~b} \pm 0.04$ & 7.8 \\
\hline
\end{tabular}

Where: Turbidity (NTU), EC: Electrical Conductivity $\left(\mathrm{mS} \mathrm{cm}^{-1}\right)$, TDS: Total Dissolved Solids ( $\left.\mathrm{mg} \mathrm{L}^{-1}\right)$, VDS: Volatile Dissolved Solids (mg L-1), $\mathrm{BOD}_{5}^{20^{\circ} \mathrm{C}}$ : Soluble Biochemical Oxygen Demand $\left(\mathrm{mgO}_{2} \mathrm{~L}^{-1}\right), \mathrm{COD}_{\mathrm{S}}$ : Soluble Chemical Oxygen Demand $\left(\mathrm{mgO}_{2} \mathrm{~L}^{-1}\right), \mathrm{BOD}_{5}{ }^{20^{\circ} \mathrm{C}} / \mathrm{COD}_{\mathrm{S}}$ : dimensionless. 
For the parameters $\mathrm{pH}, \mathrm{EC}$ and biodegradability (Table 7) a statistically significant difference $(p<0.05)$ was observed between the affluent and effluent of T9 (TDH of 17.2 minutes) and T10 (TDH of 90.6 minutes). For the parameter $\mathrm{COD}_{\mathrm{s}}$ concentration a statistically significant difference $(p<0.05)$ was observed only between the average influent and effluent of T9, and for TDS concentration the same was observed only for T10. For the parameters turbidity and concentration of VDS and $\mathrm{BOD}_{5}{ }^{20} \mathrm{C}$, statistically significant differences were observed at $5 \%$ probability ( $p>0.05)$, between the average influent and effluent of $\mathrm{T} 9$ and $\mathrm{T} 10$.

Table 8 presents the values of $\mathrm{pH}$, turbidity, EC, concentrations of VDS, CODS, $\mathrm{BOD}_{5}{ }^{20^{\circ} \mathrm{C}} \mathrm{S}$ and the $\mathrm{BOD}_{5}^{20^{\circ} \mathrm{C}} / \mathrm{COD}_{\mathrm{S}}$ ratio that characterize the influent and effluent of treatments 11 and 12 .

For the parameters turbidity and concentration of VDS statistically significant differences were

Table 7. Results of the physicochemical analysis of test 5 and the statistical comparison between averages of the influent and effluent for treatments 9 (T9) and 10 (T10).

\begin{tabular}{|c|c|c|c|c|c|c|}
\hline \multirow{2}{*}{ Parameter } & \multicolumn{2}{|c|}{ Influents T9 and T10 } & \multicolumn{2}{|c|}{ Effluent T9 } & \multicolumn{2}{|c|}{ Effluent T10 } \\
\hline & $\mathrm{A} \pm \mathrm{SD}$ & V. C. $(\%)$ & $\mathrm{A} \pm \mathrm{SD}$ & V. C. $(\%)$ & $\mathrm{A} \pm \mathrm{SD}$ & V. C. $(\%)$ \\
\hline Turbidity & $1073.0 \mathrm{a} \pm 3.0$ & 0.3 & $1066.3 \mathrm{a} \pm 2.5$ & 0.2 & $1068.0 \mathrm{a} \pm 1.0$ & 0.1 \\
\hline $\mathrm{pH}$ & $7.5 \mathrm{a} \pm 0.01$ & 0.1 & $7.8 \mathrm{~b} \pm 0.1$ & 0.8 & $7.8 b \pm 0.01$ & 0.2 \\
\hline $\mathrm{EC}$ & $4.7 \mathrm{a} \pm 0.05$ & 0.1 & $13.6 b \pm 0.2$ & 1.2 & $13.4 b \pm 0.7$ & 5.2 \\
\hline TDS & $2061.1 \mathrm{a} \pm 50.0$ & 2.4 & $2009.6 \mathrm{a} \pm 81.9$ & 4.1 & $1889.6 b \pm 46.8$ & 2.5 \\
\hline VDS & $1073.3 \mathrm{a} \pm 48.9$ & 4.6 & $1152.6 \mathrm{a} \pm 65.1$ & 5.6 & $1028.9 \mathrm{a} \pm 67.8$ & 6.6 \\
\hline $\mathrm{COD}_{\mathrm{S}}$ & $2239.3 \mathrm{a} \pm 303.6$ & 13.6 & $1307.4 b \pm 95.0$ & 7.3 & $1731.2 \mathrm{a} \pm 327.3$ & 19.0 \\
\hline $\mathrm{BOD}_{5}^{20^{\circ} \mathrm{C}} \mathrm{s}$ & $1330.0 \mathrm{a} \pm 30.0$ & 2.2 & $1260.0 \mathrm{a} \pm 105.8$ & 8.3 & $1306.7 \mathrm{a} \pm 80.8$ & 6.2 \\
\hline $\mathrm{BOD}_{5}{ }^{20^{\circ} \mathrm{C}} / \mathrm{COD}_{\mathrm{S}}$ & $0.6 \mathrm{a} \pm 0.1$ & 11.4 & $0.9 \mathrm{~b} \pm 0.02$ & 2.5 & $0.8 \mathrm{~b} \pm 0.1$ & 11.8 \\
\hline
\end{tabular}

Where: Turbidity (NTU), EC: Electrical Conductivity $\left(\mathrm{mS} \mathrm{cm}^{-1}\right)$, TDS: Total Dissolved Solids ( $\left.\mathrm{mg} \mathrm{L}^{-1}\right)$, VDS: Volatile Dissolved Solids $\left(\mathrm{mg} \mathrm{L}^{-1}\right), \mathrm{BOD}_{5}^{20^{\circ} \mathrm{C}} \mathrm{s}$ : Soluble Biochemical Oxygen Demand $\left(\mathrm{mgO}_{2} \mathrm{~L}^{-1}\right), \mathrm{COD}_{\mathrm{S}}$ : Soluble Chemical Oxygen Demand $\left(\mathrm{mgO}_{2} \mathrm{~L}^{-1}\right), \mathrm{BOD}_{5}^{20^{\circ} \mathrm{C}} / \mathrm{COD}_{\mathrm{S}}$ : admensional.

Table 8. Results of the physicochemical analysis of test 6 and the statistical comparison between the averages of the influent and effluent for treatments 11 (T11) and 12 (T12).

\begin{tabular}{lcccccc}
\hline \multirow{2}{*}{ Parameter } & \multicolumn{2}{c}{ Influent T11 and T12 } & \multicolumn{2}{c}{ Effluent T11 } & \multicolumn{2}{c}{ Effluent T12 } \\
\cline { 2 - 7 } & $\mathrm{A} \pm \mathrm{SD}$ & $\mathrm{V} . \mathrm{C} .(\%)$ & $\mathrm{A} \pm \mathrm{SD}$ & V. C. $(\%)$ & $\mathrm{A} \pm \mathrm{SD}$ & V. C. (\%) \\
\hline Turbidity & $911.0 \mathrm{a} \pm 1.0$ & 0.1 & $899.0 \mathrm{~b} \pm 3.5$ & 0.4 & $852.0 \mathrm{~b} \pm 27.9$ & 3.3 \\
$\mathrm{pH}$ & $7.7 \mathrm{a} \pm 0.02$ & 0.3 & $7.8 \mathrm{a} \pm 0.01$ & 0.1 & $7.9 \mathrm{~b} \pm 0.02$ & 0.2 \\
$\mathrm{EC}$ & $4.5 \mathrm{a} \pm 0.1$ & 1.2 & $4.6 \mathrm{a} \pm 0.0$ & 0.1 & $4.6 \mathrm{a} \pm 0.02$ & 0.3 \\
$\mathrm{TDS}$ & $2042.5 \mathrm{a} \pm 402.5$ & 19.7 & $1723.3 \mathrm{a} \pm 16.7$ & 1.0 & $1715.6 \mathrm{a} \pm 33.4$ & 2.0 \\
$\mathrm{VDS}$ & $795.0 \mathrm{a} \pm 31.7$ & 4.0 & $861.7 \mathrm{~b} \pm 5.0$ & 0.6 & $871.1 \mathrm{~b} \pm 45.5$ & 5.2 \\
$\mathrm{COD}_{\mathrm{S}}$ & $2707.5 \mathrm{a} \pm 75.9$ & 2.8 & $2723.3 \mathrm{a} \pm 161.3$ & 5.9 & $2680.0 \mathrm{a} \pm 343.3$ & 12.8 \\
$\mathrm{BOD}_{5}{ }_{\mathrm{O}}^{20^{\circ} \mathrm{C}}$ & $400.0 \mathrm{a} \pm 120.0$ & 30.0 & $410.0 \mathrm{a} \pm 70.0$ & 17.1 & $373.3 \mathrm{a} \pm 194.3$ & 52.3 \\
$\mathrm{BOD}_{5}{ }_{\mathrm{S}}^{20^{\circ} \mathrm{C}} / \mathrm{COD}_{\mathrm{S}}$ & $0.2 \mathrm{a} \pm 0.05$ & 32.6 & $0.2 \mathrm{a} \pm 0.03$ & 22.9 & $0.2 \mathrm{a} \pm 0.09$ & 58.8 \\
\hline
\end{tabular}

Where: Turbidity (NTU), EC: Electrical Conductivity $\left(\mathrm{mS} \mathrm{cm}^{-1}\right)$, TDS: Total Dissolved Solids ( $\left.\mathrm{mg} \mathrm{L}^{-1}\right)$, VDS: Volatile Dissolved Solids $\left(\mathrm{mg} \mathrm{L}^{-1}\right), \mathrm{BOD}_{5}^{20^{\circ} \mathrm{C}}$ : Soluble Biochemical Oxygen Demand $\left(\mathrm{mgO}_{2} \mathrm{~L}^{-1}\right), \mathrm{COD}_{\mathrm{S}}$ : Soluble Chemical Oxygen Demand $\left(\mathrm{mgO}_{2} \mathrm{~L}^{-1}\right), \mathrm{BOD}_{5}^{20^{\circ} \mathrm{C}}{ }_{\mathrm{S}} / \mathrm{COD}_{\mathrm{S}}$ : dimensionless. 
observed $(\mathrm{p}<0.05)$ between the influent and effluent of T11 (TDH of 3.5 minutes) and T12 (TDH of 12.3 minutes). When analyzing $\mathrm{pH}$ a statistically significant difference was observed $(\mathrm{p}<0.05)$ only between the average influent and effluent of T12. However, with regards to the parameters $\mathrm{EC}$, concentrations of TDS, $\mathrm{COD}, \mathrm{BOD}_{5}^{20^{\circ} \mathrm{C}} \mathrm{s}$ and biodegradability no statistically significant difference was observed at $5 \%$ probability $(p>0.05)$, between the average affluent and effluent of T11 and T12.The use of photolysis $(230 \mathrm{~nm})$ is a suitable method for photo-degradation of soluble organic matter (tables 3 to 8); and it can be concluded that for the parameters of turbidity, $\mathrm{EC}$, concentrations of VDS, CODs, BODs ${ }_{5}^{20^{\circ} \mathrm{C}}$ and $\mathrm{BOD}_{5}{ }^{20^{\circ} \mathrm{C}} / \mathrm{COD}_{\mathrm{S}}$ ratio the results did not provide a response or behavior pattern when all tests were analyzed together. This was probably due to the variation of the applied loading rates and the various by-products formed during photolysis that may interfere in the final constitution of treated effluents.

Ye et al. (2013) evaluated the use of photolysis with UV radiation at wavelength $206 \mathrm{~nm}$ as a process for degradation of contaminants including triphenyl chloride (TPTCl), dimethyl phthalate (DMP) and rhodamine B (RHB) in wastewater. The concentrations of TPTCl, DMP and RHB used in the experiment were $120 \mathrm{mg} \mathrm{L}^{-1}, 60 \mathrm{mg} \mathrm{L}^{-1}$ and $50 \mathrm{mg} \mathrm{L}^{-1}$, respectively. These compounds were separately subjected to high UV radiation for 75 min, $50 \mathrm{~min}$ and $60 \mathrm{~min}$, obtaining the following degradation efficiencies of $89.4 \%, 92.5 \%$ and $88.6 \%$, respectively. The authors presented the photo-degradation mechanism of each organic compound evaluated. Based on these results, it was observed that photo-degradation produced several intermediate by-products from the degraded compounds, in which case the wastewater after the photolysis process presented various characteristics with regards to its composition, even when the reagent is from a pure substance. Similar statements about the reaction mechanism and formation of by-products from the photodegradation of pure substances were also made by Fang et al. (2013), who studied photolysis by UV radiation with a wavelength of $254 \mathrm{~nm}$ for the degradation halo-nitromethanes.
Based on the studies conducted by Ye et al. (2013) and Fang et al. (2013) on photolysis of pure substances, it can be affirmed that the same diversity of by-products from photo-degradation and intermediate compounds can also occur during photolysis of swine wastewater since it contains a complex matrix of components, including carbohydrates, proteins, oils and greases and other compounds with complex organic chain. Due to this diverse composition there may have occurred the formation of several by-products in the final effluent of the treatments studied, which contributed to the non-uniformity of the behavioral results for biodegradability, turbidity, EC and $\mathrm{pH}$ after photolysis.

Yoon et al. (2014) evaluated the use of AOP (individual ozonation combined with hydrogen peroxide) for removing color from swine wastewater after being subjected to treatment with ultrafiltration membranes (UF), obtaining an effluent with total COD concentration of $350 \mathrm{mgO}_{2} \mathrm{~L}^{-1}$ and color of 550 to $600 \mathrm{PtCo}$. With nanofiltration membranes (NF) it was possible to obtain an effluent with total COD concentration of $280 \mathrm{mgO}_{2}$ $\mathrm{L}^{-1}$ and color of 400 to $500 \mathrm{PtCo}$. The results found for removing color from swine wastewater influent using the UF process, in combination of ozonation with hydrogen peroxide at a mass/mass proportion $\left(\mathrm{wt} / \mathrm{wt}\right.$ ) of 1:0.7, with ozone dose of $240 \mathrm{mgO}_{3} \mathrm{~L}^{-1}$ applied at a rate of $10 \mathrm{mgO}_{3} \mathrm{~L}^{-1} \mathrm{~min}^{-1}$ for $24 \mathrm{~min}$, $20^{\circ} \mathrm{C}, \mathrm{pH} 8$, was the best experimental condition evaluated, resulting in $90 \%$ color removal. Color removal from swine wastewater using the $\mathrm{NC}$ process showed that ozonation alone, with ozone dose of $105 \mathrm{mgO}_{3} \mathrm{~L}^{-1}$ applied at a rate of $10 \mathrm{mgO}_{3}$ $\mathrm{L}^{-1} \mathrm{~min}^{-1}$ during 12 minutes at $20^{\circ} \mathrm{C}$ and $\mathrm{pH} 8$, was the best experimental condition evaluated, resulting in $90 \%$ color removal.

Yoon et al. (2014) reported the difficulty in removing color, and therefore dissolved solids (VDS and TDS) from swine wastewater, even after treatment with NF and UF membranes. The cited work indicated that to remove $90 \%$ of color it was necessary to use high oxidant doses (ozone and hydrogen peroxide), and required high reaction times. When analyzing tables 3, 4 and 7 it is possible to conclude that there was no statistically significant difference $(p<0.05)$ between the 
averages of the influent and effluent with regards to TDS and VDS concentrations, indicating that there was no removal of this parameter when submitted to the treatment process. For the other operating conditions described in tables 5,6 and 8, low removal efficiencies were found. The results obtained in this experiment (Table 2) show that photolysis used as a single photo-degradation process, without the aid of oxidants, is inefficient for removal of VDS and TDS, as explained by Yoon et al. (2014).

Since the biodegradability ratio of the effluent to affluent suffered modification due to exposure of UV in the photo-reactor, the ratio may either increase or decrease depending on operational parameters involved. When analyzing tables 4 and 5 that present the data with regards to tests 2 and 3 , respectively, it is observed that biodegradability in the effluent decreases in relation to the affluent. However, when analyzing Table 6 (treatment 8 ) and Table 7 with data from tests 4 and 5, respectively, an increase in biodegradability of the effluent in relation to the influent was observed.

Al-Momani et al. (2002) studied the use of photolysis by UV radiation for increasing the biodegradability of wastewater from the textile industry. The authors submitted the wastewater to various radiation exposure times and quantified the $\mathrm{BOD}{ }_{5}^{20^{\circ} \mathrm{C}} / \mathrm{COD}_{\mathrm{S}}$ ratio. They concluded that photolysis could increase biodegradability since the wastewater is exposed to a UV irradiation time in ideal conditions of concentration, color and other specific characteristics. Therefore, when analyzing the operational parameters submitted to photo-reactors during tests 2 and 3 (Table 2), in conjunction with the results obtained after treatment (tables 4 and 5), it was observed that the conditions to reduce biodegradability of the swine wastewater effluent were: HRT between 1.5 and 14.6 minutes, TDSL between 267.4 and 3080.6 gTDSd$^{-1}$,CODL between 376.6 and 3362.2 $\mathrm{gCODd}^{-1}$, BODL between 183.5 and $1915.2 \mathrm{gBOD}$ $\mathrm{d}^{-1}$,obtaining values of the $\mathrm{BOD}_{5}^{20^{\circ} \mathrm{C}} \mathrm{s}_{\mathrm{S}} \mathrm{COD}_{\mathrm{S}}$ ratio (biodegradability), minimum COD of up to 0.3 , with $50 \%$ maximum biodegradability reduction (from 0.6 to 0.3 ).However, when analyzing the operational parameters of the photo-reactor during test 4 and 5 (Table 2), in conjunction with the results obtained after treatment (tables 6 and 7), it was observed that the conditions for the increase in biodegradability of the effluent were: HRT between 14.7 and 90.6 minutes, TDSL between 49.0 and 284.4 gTDS d$^{-1}$, CODL between 53.2 and $384.1 \mathrm{gCOD} \mathrm{d}^{-1}$, BODL between 31.6 and 167.3 $\mathrm{gBOD} \mathrm{d}^{-1}$, obtaining maximum values of $\mathrm{BOD}_{5}{ }^{20^{\circ} \mathrm{C}} \mathrm{s}$ $\mathrm{COD}_{\mathrm{S}}$ (biodegradability) of up to 0.9 , with average biodegradability increase of up to $50 \%$ (from 0.6 to 0.9 ). For test $1, \mathrm{~T} 7$ in of test 4 and all of test 6 , biodegradability of the effluent did not present a statistically significant difference $(p>0.05)$ compared to the influent.

Pereira et al. (2014) used two photo-reactors for polishing of swine wastewater in an anaerobic reactor system, with constructive and operational parameters identical to this study, however, they investigated the removal of total and thermoresistant coliforms. According to the authors, the experimental condition that presented the best performance was described by assay 5 , test 10 (Table 7), when subjecting the wastewater to HRT of 90.6 minutes. At these conditions they obtained total and thermo-resistant coliform removal efficiencies of $100 \%$ for both log units, removal of 7.8 and 9.4, respectively, and bacterial decay constant of $5.98 \times 10^{2} \mathrm{~d}^{-1}$ for both.

In an attempt to study the removal of pathogens simultaneously with dissolved organic material from swine wastewater, the same parameters used by Pereira et al. (2014) were applied (Table $2)$. Based on the results shown in tables 3, 4, 5, 6,7 and 8 , it was concluded that photolysis, as a process for removal of dissolved organic matter and modification of biodegradability, presented low efficiency.

\section{CONCLUSIONS}

- Based on the results obtained in this study and from other studies published and cited during the discussion of the results obtained, it is possible to affirm that the use of UV radiation alone is not sufficient to mineralize dissolved organic matter, requiring the use of an oxidizing process in order to achieve complete or high removal percentages; 
- It is possible to increase or decrease the biodegradability of swine wastewater using photolysis with UV radiation without the use of oxidants; however, the operating application must be correct in order to achieve this goal. It is important to stress in this present work that the experimental conditions of tests 3 and 5 have gained prominence in terms of reducing organic matter and increasing biodegradation (mineralization) due to the UV radiation process.

\section{ACKNOWLEDMENTS}

The authors are grateful to the Water Analysis Laboratory of the Engineering Department (LAADEG/UFLA) for carrying out the analyses, as well as the financial support of FAPEMIG used for facilities and equipment installed in the pilot system, through the Project TEC 1550/03. The authors also acknowledge $\mathrm{CNPq}$ for granting of scholarships.

\section{BIBLIOGRAPHIC REFERENCE}

ABREU, P.; PEREIRA, E.L.; CAMPOS, C.M.M.; NEVES, F.L. Oxidation Process $\left(\mathrm{UV} / \mathrm{H}_{2} \mathrm{O}_{2} /\right.$ $\mathrm{ZnO}$ ) in the treatment and sterilization of dairy wastewater. Acta Scientiarum Technology, v.35, n.1, p.75-81, 2013.

AL-MOMANI, F.; TOURAUD, E.; DEGORCEDUMAS, J.R.; ROUSSY, J.; THOMAS, O. Biodegradability enhancement of textile dyes and textile wastewater by UV photolysis. Journal of Photochemistry and Photobiology A: Chemistry, v.153, p.191-197, 2002.

AMERICAN PUBLIC HEALTH ASSOCIATION. Standard methods for the examination of water and wastewater. Washington. 2005.

CONSELHO NACIONAL DO MEIO AMBIENTE - CONAMA. Resolução $\mathbf{n}^{0}$ 357, de 17 de março de 2005. Dispõe sobre a classificação dos corpos de água e diretrizes ambientais para o seu enquadramento, bem como estabelece as condições e padrões de lançamento de efluentes, e dá outras providências.
FANG, J.Y.; LING, L.; SHANG, C. Kinetics and mechanisms of $\mathrm{pH}$-dependent degradation of halonitromethanes by UV photolysis. Water Research, v.47; p.1257-1266; 2013.

FERREIRA, D.F. Sisvar: a computer statistical analysis system. Ciência e Agrotenologia, v.35, p.1039-1042, 2011.

FERREIRA, I.V.L.; DANIEL, L.A. Fotocatálise Heterogênea com $\mathrm{TiO}_{2}$ aplicada ao tratamento de esgoto sanitário secundário.Engenharia Sanitária e Ambiental, v.9, n.4, p.335-342, 2004.

LIM, S.J.; KIM, T.H.; LEE, S.H.; KIM, J.Y.; KIM, S.K. Effects of electron beam irradiation and temperature on the treatment of swine wastewater using an ion exchange biological reactor. Bioresource Technology, v.137, p.233-238, 2013.

PEREIRA,E.L.;CAMPOS, C.M.M.;MOTERANI, F. Efeitos do $\mathrm{pH}$, acidez e alcalinidade na microbiota de um reator anaeróbio de manta de lodo (UASB) tratando efluentes de suinocultura. Revista Ambiente \& Água, v.4, n.4 p.157-168, 2009.

PEREIRA, E.L.; CAMPOS, C.M.M.; MOTERANI, F. Evaluation of physical-chemical performance of an UASB reactor in removing pollutants of pig wastewater. Revista Ambiente e Água. v.5, n.2, p.79-88, 2010a.

PEREIRA, E.L.; CAMPOS, C.M.M.; MOTERANI, F. Physical-chemical and operational performance of an anaerobic baffled reactor (ABR) treating swine wastewater. ActaScientiarum. Technology, v.32, n.2, p.399-405, 2010 b.

PEREIRA, E.L.; CAMPOS, C.M.M.; MOTERANI, F.; OLIVEIRA NETO, A.M. Eficiência de um sistema de reatores anaeróbios no tratamento de efluentes líquidos de suinocultura. ActaScientiarum Technology, v.33, n.3, p.287293, 2011a.

PEREIRA, L.C.O.; ROSSO, T.; CAMPOS, J.C.; GIORDANO, G. Fenton's reagent application 
in the domestic sewers disinfection. Revista Ambiente e Água, v.6, n.1, p.65-76, 2011 b.

SALGADO, B.C.B.; NOGUEIRA, M.I.C.; RODRIGUES, K.A.; SAMPAIO, G.M.M.S.; BUARQUE, H.L.B.; ARAÚJO, R.S. Descoloração de efluentes aquosos sintéticos e têxtil contendo corantes índigo e azo via processos Fenton e fotoassistidos (UV e UV/ $\left.\mathrm{H}_{2} \mathrm{O}_{2}\right)$. Engenharia Sanitária e Ambiental, v.14, n.1, 2009.

SUBTIL, E., MIERZWA, J., HESPANHOL, I.. Avaliação do desempenho do sistema $\mathrm{UV} / \mathrm{H}_{2} \mathrm{O}_{2}$ no tratamento de efluentes provenientes do processo de tratamento térmico de emulsões de água e óleo. Revista Ambiente e Água, v.4, n.3, p.169-180, 2009.

YOON, Y; HWANG, Y.; KWON, M.; JUNG, Y.; HWANG, T.M.; KANG, J.W. Application of $\mathrm{O}_{3}$ and $\mathrm{O}_{3} / \mathrm{H}_{2} \mathrm{O}_{2}$ as post-treatment processes for color removal in swine wastewater from a membrane filtration system. Journal of industrial and engineering chemistry, v. 20, p.2801-2805, 2014.

YE, Z.L.; CAO, C.Q.; HE, J.C.; ZHANG, R.X.; HOU, H.Q. Photolysis of organic pollutants in wastewater with $206 \mathrm{~nm}$ UV irradiation. Water research, v.47, p.1257-1266, 2013. 